\title{
Islamic Banking and Financial Inclusion: Evidence from Asian and African Markets
}

\author{
Waheed Akhter ${ }^{1 *}$, Muhammad Umer Majeed ${ }^{2}$, David Roubaud ${ }^{3}$ \\ ${ }^{1}$ Assistant Professor, Center of Islamic Finance, COMSATS University Islamabad (CUI), \\ Lahore, Pakistan \\ ${ }^{2}$ Economics and Finance Department, Henan University, Kaifeng, China \\ ${ }^{3}$ Montpellier Business School, Montpellier Research in Management, Montpellier, France
}

\section{Keywords \\ Financial Inclusion \\ Islamic Banking \\ Asian and African \\ Financial Markets}

Received: 13-May-19

Accepted: 19-Aug-19

\begin{abstract}
Very few researchers have attempted to assess the impact of Islamic banking on both the demand and the supply sides of financial inclusion. Our study fills this gap by investigating 14 middle and 14 lower income countries from Asia and Africa over the period 2005-2014. Random effects panel regression technique based on Hausman's specification test has been used to analyse the data. Results indicate that Islamic banking is significantly contributing to the demand side of financial inclusion (borrowers' side or the users of banks financing). This research has important policy implications for regulatory authorities of Muslim countries to enhance financial inclusion.
\end{abstract}

KAUJIE Classification: H13, J3

JEL Classification: G2, G1, E2

(C) 2019 JIBM. All rights reserved.

\section{INTRODUCTION}

During the past two decades, the Islamic finance industry across worldwide has shown unprecedented growth. Islamic finance assets around the globe increased from US\$2.4 trillion in 2017 to US $\$ 2.5$ trillion in 2018. Such assets are expected to reach $\$ 3.4$ trillion by 2024 (ICD-Rifinitiv, 2019). However, despite the growth of Islamic finance in both Muslim and non-Muslim countries across the world, a sizeable proportion of the world population remains excluded from mainstream financial services. Financial inclusion aims at reaching the 'unbanked' population so that they can have the access to financial services ranging from opening saving accounts, online payments, transfers of funds and insurance services (Hannig \& Jansen, 2010).

\footnotetext{
*Corresponding author: Waheed Akhter

†Email: drwaheed@cuilahore.edu.pk
} 
Financial inclusion is an emerging research topic ${ }^{1}$. More than $50 \%$ of the world's adult population (over 2.5 billion) do not possess any formal account with a financial institution; of these, 5 per cent cite religious reasons for not having an account (World Bank, 2014). This means that more than 100 million individuals remain excluded from having a formal bank account for religious reasons.

Although the worldwide share of financial exclusion for religious reasons is relatively small overall, it is much higher in Muslim countries ${ }^{2}$. Geographically, in African countries the level of financial inclusion is very low, especially in rural poorer communities, due to issues of income and barriers to accessing financial institutions (El-Zoghbi \& Tarazi, 2013). Complex financial services and products, financial institutions' locations, and lack of proper documentation are also key reasons for financial exclusion. Despite the current quick transformation of communication and information technologies, African countries' financial infrastructures remain insufficient, and financial inclusion is an urgent challenge. In some regions of Africa, bank penetration is less than 10 per cent of the population. Financial inclusion is also a persistent challenge in Asian countries. Fungacova and Weill (2015) conducted thorough research on this topic. They used three indicators of financial inclusion in their research (i.e., bank credit use, ownership of a bank account, and saving in bank accounts). They found that the countries with high income benefit from a higher level of individual bank account ownership. They also concluded that, in terms of savings accounts or the use of formal credit, practices differ widely depending on financial inclusion and per capita income.

This study aims to investigate the impact of Islamic banking on financial inclusion in Muslim countries of Asia and Africa given the recent development, growth of Islamic finance and stylized facts about financial inclusion among Muslims. The reason is that Muslim populations are often large both in number and proportion in the societies of the study, it is important to question the potential impact of innovative Islamic banking solutions and approaches. To achieve the objective of overall human welfare, and in line with the wider concept of maqāsid al-Sharī'ah, this study focuses on selected Asian and African markets where Islamic banking operations exist and the population are mainly Muslims. We selected 28 middle and lower-income countries of Asia and Africa for the period of 2005-2014. We found a positive impact of Islamic banking on financial inclusion across both regions, especially on the demand side (borrowers' side).

The contribution of this study is twofold. First, it contributes to the literature by identifying the key role of both Islamic finance and financial inclusion in the economic development of countries and establishes the potential role of Islamic finance in increasing financial inclusion. Second, it empirically assesses the impact of Islamic finance on financial inclusion in the

\footnotetext{
${ }^{1}$ A World Bank report (2014) underlined that more than half of the agencies and regulatory agencies have been tasked to work on financial inclusion and promote it. Approximately 50 countries have set targets for financial inclusion.

${ }^{2}$ Another reason for this higher financial exclusion in Muslim countries is their higher poverty level. It is estimated that, in developing countries, around 650 million Muslims live on less than $\$ 2$ per day. The poorest $40 \%$ of these remain without any formal bank account and $35 \%$ of small firms face difficulty in accessing formal financial services (El-Zoghbi \& Tarazi, 2013; Sahay et al., 2015; World Bank, 2014).
} 
Asian and African regions and identifies its significant contribution on the demand side (borrowers' side) of financial inclusion. Consequently, the study has important implications for policy makers in Muslim countries.

The study is divided into five sections. After giving introduction on the role of Islamic finance in financial inclusion in the first section, next section covers relevant literature review. Third section discusses methodology to see the impact of Islamic banking on financial inclusion. Fourth section provides results and their discussion. The last section concludes the paper.

\section{LITERATURE REVIEW}

Given the high level of financial exclusion among Muslims due to religious reasons, Islamic banking can play a vital role in enhancing financial inclusion among Muslim countries. Several researchers have attempted to establish relationship between Islamic finance (including Islamic banking and Islamic microfinance) and financial inclusion (Ahmed 2002; Aysan, Disli, Ng, \& Ozturk, 2016; Demirgüç-Kunt, Klapper, Singer, \& Van Oudheusden, 2015; Demirgüç-Kunt, Klapper, \& Singer, 2017; El-Zoghbi \& Tarazi, 2013; Iqbal \& Shafiq, 2015; Léon \& Weill, 2017; Mohieldin, Iqbal, Rostom, \& Fu, 2012; Naceur, Barajas, \& Massara, 2015; Shaikh, Ismail, Shafiai, Ismail, \& Shahimi, 2017; Weill, 2011; Weill \& Godlewski, 2014). Some of the studies have focused on the OIC countries; some have included both Muslim and non-Muslim countries; and many are single country studies. Notably, most of the studies have assessed the impact of Islamic banking on the demand side (i.e., borrowers' side) of financial inclusion. On the other hand, very few researchers have attempted to assess the impact of Islamic banking on both the demand side and supply side (depositors' side) of financial inclusion (e.g., Demirgüç-Kunt et al., 2017; Naceur et al., 2015).

If one of the strongest obstacles to financial inclusion is the shortage of money available, infrastructure matters a lot for financial inclusion. Around the globe, almost half ( 2.5 billion) of adults do not use formal services. Sinclair (2001) underlined that, in addition to lack of access to financial services or their costs, dissatisfaction and bad client experiences, as well as negative word of mouth, are also major reasons for self-exclusion. Zinsa and Weill (2016) attempted to investigate the determinants of financial inclusion in Africa using a sample of 37 countries. They found that income and education had significant impacts on financial inclusion in Africa. To explore the behavioural dimensions of micro-credit, Bauer, Chytilová, and Morduch (2012) found that micro-credit contracts are helpful for people who lack suitable savings instruments. Ghosh and Vinod (2017) revealed that education and lower wages were the key factors affecting access to finance among households headed by females. On the supply side (use of finance), political and social factors were the prominent drivers. Fungáčová and Weill (2015) found a high level of financial inclusion in China, indicated by a greater number of formal accounts and high levels of formal savings. Income, education, gender, and age were found to be the contributing factors.

At the firm level, Weill and Godlewski (2014) analysed a dataset of Middle East and Southeast Asian countries over the period 2001-2009. They identified proportion of Muslim population, institutional quality, and financial development as the key determinants for a 
preference of Islamic financing. The International Finance Corporation (2014) revealed that $20 \%$ of Small and Medium-sized Enterprises (SMEs) did not borrow from conventional banks due to religious reasons. Ahmed (2002) argued that Islamic Monetary Financial Institutions (MFIs) had the potential to better serve the poorest of the poor and could mitigate the problems created by conventional MFIs. Islamic microfinance is recognized as an important Sharī'ah compliant instrument to provide financial services to those who are excluded from mainstream financial services. Hence by reaching the poorest of the poor, Islamic microfinance could play the role of integrating the vulnerable segment of society into the mainstream financial system (Islamic Financial Services Board, 2013). Naceur et al. (2015) investigated the impact of Islamic banking development on financial inclusion in Muslim (OIC) countries. They suggested that Islamic banking can be an effective avenue for the inclusion of financially excluded Muslims.

While financial inclusion benefits from Islamic banking, it appears that Muslim populations are often lagging in this regard. Demirgüç-Kunt, Klapper, and Randall (2014) explored the use and demand for formal financial services among over 65,000 adults in 64 countries. They concluded that Muslim adults were less likely to have an account at a formal financial institution as compared to non-Muslims. They argued that Muslim adults preferred Sharī'ah compliant products, despite their higher costs.

Table 1 offers an overview of financial inclusion statistics; it illustrates the differences between Asia and Africa, emphasizing the case of Pakistan as a large Muslim country with very limited financial inclusion, and underlines differences between rural and urban areas, as well as gender inequality.

TABLE 1

Geographical Statistics of Financial Inclusion

\begin{tabular}{llll}
\hline \hline & $\begin{array}{l}\text { Pakistan } \\
\text { \% of Total } \\
\text { Population }\end{array}$ & $\begin{array}{l}\text { South Asia } \\
\text { \% of Total }\end{array}$ & $\begin{array}{l}\text { Sub-Saharan Africa } \\
\text { \% of Total Population }\end{array}$ \\
\hline All adults & 10.3 & 33 & 24.1 \\
Male adults & 17.3 & 40.7 & 26.7 \\
Female adults & 3 & 25 & 21.4 \\
Adults living in rural areas & 7.2 & 30.8 & 20.7 \\
Adults living in urban areas & 15.4 & 39.2 & 39.7 \\
\hline \hline
\end{tabular}

Source: World Bank (2014)

Some studies have assessed the impact of Islamic banking development on economic growth and sustainability. For example, Imam and Kpodar (2016) found that Islamic banking development positively contributed to economic growth of the countries and improved financial inclusion. Imam and Kpodar (2010) examined the pattern of Islamic banking diffusion across the world, using country level data over the period 1992-2006. They found that per capita income, share of Muslim population, and status as an oil producing country are the key factors behind Islamic banking development in countries. Mohieldin et al. (2012) showed that, as compared to non-Muslims, the ratio of Muslims who used financial services 
was lower ${ }^{3}$.

Recent studies have shown promising role of Islamic finance in enhancing financial inclusion. For example, Jouti (2018) assessed the impact of Islamic finance on financial inclusion and found that Islamic finance might not only enhance financial inclusion, but also trigger financial migration. Shinkafi, Yahaya, and Sani (2019) adopted a theoretical approach to find out determinants of financial inclusion in the context of Islamic finance. They found that robust technology, regulatory authority's commitment and awareness about Islamic financial services were the key drivers to enhance financial inclusion.

\section{METHODOLOGY}

We collected data from World Development Indicators (WDI) and the Global Financial Development Report (GFDR) and covered the 10-year period of 2005-2014. Our sample includes 28 middle and lower income OIC member countries, further categorized into two sub-samples based on the Asian and African regions ${ }^{4}$. The data is primarily based on financial inclusion, Islamic banking assets of Asian and African countries, and control variables (GDP per capita, banking competition, depth of credit information, strength of legal rights and financial development). Our model, as given below, shows the relationship between the independent and dependent variables.

$$
F_{i}=\alpha+\beta_{1} X_{1}+\beta_{2} X_{2}+\beta_{3} X_{3}+\beta_{4} X_{4}+\beta_{5} X_{5}+\beta_{6} I . B_{i}+\epsilon
$$

Where $F i$ represents financial inclusion and is measured by number of Accounts per 1000 adults of both depositors as well as of Borrowers in the $i^{\text {th }}$ year. $X_{1}$ to $X_{5}$ are treated as Control variables where $X_{1}$ represents GDP per capita. $X_{2}$ represents legal rights measured by strength of legal rights and has range (week $0-$ strong 12 ). $X_{3}$ represents financial information measured by depth of credit information and has range (shallow 0 to deep 8). $X_{4}$ represents banking competition measured by Lerner index that is a measure of market power in the banking market. $X_{5}$ represents financial development measured by $M_{2}$ (broad money) as percentage of GDP per Capita. I. $B_{i}$ represents Islamic Banking measured by Islamic bank assets per capita (Islamic bank assets/number of adults) in the $i^{\text {th }}$ year.

Financial inclusion has been studied by several researchers such as Demirgüç-Kunt et al. (2015), Demirgüç-Kunt et al. (2017), Hannig and Jansen (2010), and Naceur et al. (2015). Zinsa and Weill (2016) have identified GDP per capita income as an important determinant of financial inclusion. Legal rights and financial information have been used by Naceur et al. (2015) as control variables. Banking competition has been measured through Love and Pería (2015). Finally, financial development has been used by the World Bank (2014).

\footnotetext{
${ }^{3}$ Chiu, Newberger, and Paulson (2005) divided Muslims in categories according to their preferences towards conventional vs. Islamic banking: (i) people who reject conventional financial products due to prohibition by Sharī'ah, (ii) those who do not wish to be restricted to Islamic banking, and (iii) those who use conventional financing but could switch to Islamic banking.

${ }^{4}$ The subsamples are equally divided; the list of countries is shown in Appendix 1.
} 


\section{RESULTS AND DISCUSSION}

\section{Descriptive Statistics}

Table 2 presents the descriptive statistics across regions to analyse the cross-regional differences. The statistics include the mean, minimum, maximum, standard deviation, skewness and kurtosis values of the main variables used in this study. These variables are used to determine their impact on financial inclusion.

In the cross-regional comparative descriptive analysis, we found that the strength of legal rights and depth of credit information are noticeably higher in the Asian region than in the African region, at 4.10 and 2.81 in Asia, and 3.38 and 0.78 in Africa, respectively. The value for banking competition is 0.18 across the Asian region, lower than 0.25 in the African region. This indicates that there is more banking competition in the Asian region than in the African region. Considering the mean, Islamic banking assets and per capita income are higher in the Asian region on a mean basis than the African region at 4008.47 and 622.46, and 1536.85 and 89.44, respectively. The larger difference between values of these variables across and within the regions shows the wide range differences across the sample because of regional and country differences.

In the graphs ${ }^{5}$, we have presented the annual change in the dependent and independent variables over the period 2005-2014. The graphs also indicate that Islamic banking is contributing more to financial inclusion in the Asian region than in the African region.

TABLE 2

Descriptive Statistics of Asia and Africa

\begin{tabular}{lllllllll}
\hline \hline Region & \multicolumn{3}{c}{ Asia } & \multicolumn{4}{c}{ Africa } \\
\hline Variables & Mean & S.D & Skew. & Kurtosis & Mean & S.D & Skew. & Kurtosis \\
\hline GDP Per Capita & 4008.47 & 2935.21 & 0.63 & 2.48 & 1536.85 & 1247.94 & 1.46 & 4.19 \\
Financial Development & 66 & 59 & 1.91 & 5.8 & 43.99 & 23.45 & 0.603 & 2.04 \\
Banking Competition & 0.18 & 0.16 & 0.012 & 1.722 & 0.25 & 0.19 & -0.09 & 1.89 \\
Financial Information & 2.81 & 2.51 & 0.02 & 1.43 & 0.78 & 1.73 & 2.36 & 8.0255 \\
Legal Rights & 4.1 & 2.48 & 0.55 & 2.93 & 3.38 & 1.91 & 0.199 & 2.32 \\
Islamic Banking Assets & 622.46 & 1316.16 & 2.94 & 11.35 & 89.44 & 226.54 & 3.86 & 17.99 \\
\hline \hline
\end{tabular}

Note: All dependent variable means, standard deviations, and minimum and maximum values are provided to check the central tendencies and dispersion across both Asian and African middle- \& lower-income countries. Skewness and kurtosis depict the normality of the data distributions.

\section{Financial Inclusion Cross-Regional Regression Analysis}

The impact of Islamic banking (on financial inclusion of both depositors and borrowers) in the presence of the control variables of financial development, GDP per capita, banking competition, financial information, and legal rights across both Asian and African regions are analysed for comparison purposes. Tables 3 reports the results of the models that capture both supply and demand side of financial inclusion in Asian and African markets. Models include all control variables and Islamic banking assets at same time. 
TABLE 3

Financial Inclusion in Asia and Africa

\begin{tabular}{lllll}
\hline \hline & \multicolumn{2}{c}{$\begin{array}{c}\text { Financial Inclusion } \\
\text { (Supply side) }\end{array}$} & \multicolumn{2}{c}{$\begin{array}{c}\text { Financial Inclusion } \\
\text { (Demand side) }\end{array}$} \\
\hline & Asia & Africa & Asia & Africa \\
\hline Variables & Model I & Model II & Model III & Model IV \\
\hline GDP per capita & $1.152^{* * *}$ & $0.727^{* * *}$ & 0.615 & $1.45^{* * *}$ \\
Financial development & $0.391^{*}$ & 0.244 & $.58^{* *}$ & -0.15 \\
Banking competition & $0.214^{*}$ & $0.329^{* *}$ & 0.299 & -0.2 \\
Financial information & 0.013 & -0.001 & 0.018 & -0.008 \\
Legal rights & $0.035^{*}$ & $0.026^{* *}$ & 0.014 & 0.006 \\
Islamic banking assets & $-0.43^{* * *}$ & 0.049 & $0.099^{*}$ & $0.15^{* *}$ \\
Constant & $-2.39^{* * *}$ & $-0.972^{*}$ & $-1.48^{* *}$ & $-3.38^{* * *}$ \\
Hausman Test & 2.58 & 0.58 & 1.76 & 3.09 \\
\hline \hline
\end{tabular}

Note: *** significant at the $1 \%$ level, ** significant at the 5\% level, and * significant at the $10 \%$. Level.

The Lerner index is used as a proxy for banking competition, financial information is represented by the credit information index, and the legal rights index is used for strength of legal rights. All variable data was collected from the World Bank Development Indicators database.

The results for the impact of Islamic banking on financial inclusion measured as the number of depositors (supply side) and borrowers (demand side) are presented across both the Asian and African regions. The Hausman (1978) specification test is used to select between random and fixed effects models. The Hausman test p-value is significant at the 5 percent level; therefore we accept the null hypothesis that the random effects model is significant, and use the random effects model across both the Asian and African regions.

Across all models, per capita income shows a significantly positive impact on financial inclusion measured as the number of depositors in financial institutions (banks) across both regions, but the effect is stronger in Asia. Rising per capita income due to economic development in the countries encourages people to use and save through the financial institutions as depositors. This means that per capita income increase, indicating economic growth and development in a country as well as availability of sufficient amounts to save or invest, and higher returns offered on short-term investments by banks, positively influence people to use financial institutions.

Financial development has a positive (but significant only in case of Asia) impact on financial inclusion, indicating that improving financial development leads to a higher number of depositors, further leading to more Islamic banking assets. Legal rights protection is positive and significant for financial inclusion based on the number of depositor accounts across both Asian and African regions.

The strength of financial information has a positive, but insignificant impact on financial inclusion based on number of depositor accounts in Asia; but is negative in the case of the African region in the presence of other control variables. Banking competition has a positive influence on increasing financial inclusion based on depositor accounts, as there will be higher competition among banks when they compete to attract depositors for profitability. This suggests that as banking competition increases, banks will open new branches to capture 
the market and to compete for deposits and to provide financing.

Islamic banking has a negative but significant influence across Asia, but an insignificant positive relationship across Africa. This indicates that, although Islamic banking assets are increasing, they have made a smaller contribution to financial inclusion because of their recent emergence across the globe, compared to conventional banking.

The Hausman test (1978) $p$-values are greater than our 5 percent level of significance; therefore, we accept the null hypothesis that a random effects model is significant, and thus use a random effect mode across all three for the Asian and African regions.

The results of the impact of individual variables with Islamic banks on financial inclusion as measured by the number of adult borrowers from banks (demand side) are presented on the right side of Table 3. Per capita income has a positive and significant impact on financial inclusion measured by number of borrowers. Per capita income increase shows the economic growth and development going on across countries, so to excel and enhance their businesses, they borrow from commercial banks. Legal rights protection has a positive but insignificant impact on the number of borrower accounts in commercial banks across the African and Asian regions. It shows the low level of legal rights protection environment in both regions. This indicates that better legal rights protection may positively encourage the people for opening accounts and to obtain loans from banks to fulfil their needs. For Asia, strength of financial information has a positive and significant impact on financial inclusion measured by number of borrowers' accounts in commercial banks, while it is negative in the case of Africa.

This shows that credit information strength contributes positively towards attracting borrowers and understanding loan sanction procedures for borrowers. It also suggests that if credit information is stronger, then borrowers focus on attaining loans through banks rather than going to other non-financial institutions and borrowing sources Shaikh et al. (2017). Deeper credit information makes a customer's choice for loan sanctions easy, and it helps reduce NPLs in credit portfolios across the banks. Financial developments have a positive and significant impact on financial inclusion in the Asian region, indicating that improving financial developments leading to higher Islamic banking assets leads to a higher number of borrowers, because of the enhanced banking services.

Banking competition is positive but insignificant for increasing financial inclusion through borrowers' accounts in commercial banks in the Asian region, but negative in the case of the African region. It depicts less competition and branch networking across both regions, causing less access to these banking services as confirmed by Love and Pería (2015). This indicates that increases in banking competition would cause banks to compete for available funds to provide financing, as well as for the sake of their profits, by offering diversified products and attracting depositors with new branches to capture the market. Islamic banking has a positive and significant influence on financial inclusion measured by borrowers' accounts across the African and Asian regions. This verifies that Islamic banking provides asset-based financing, so when the number of borrowers increases, Islamic banking assets also increase. Due to Sharī'ah compliance factor in Islamic banking, and the religious belief, Muslims generally prefer getting financing from Islamic banks to fulfil their needs. 


\section{CONCLUSION}

Religious beliefs are key factors in the observed lack of financial inclusion in the Muslim countries. To overcome this issue, Islamic banking development may play a favourable role, bringing financially excluded Muslims towards usage of Sharī'ah compliant services to fulfil their financial needs. We investigated the impact of Islamic banking on financial inclusion, considering borrowers, depositors and branch network dimensions.

Our findings reveal that Islamic banking positively influences financial inclusion as it increased the number of borrowers in both the African and Asian regions who especially require Islamic banking services. However, Islamic banking has shown a less convincing relationship with depositors in the Asian region, revealing that potential clients are more hesitant in the Asian region, when it comes to savings with Islamic banking. This also reveals that the lack of trust in Islamic banking, which relates to ease of access and branch networks, creates a hurdle for financial inclusion.

The results also indicate that Islamic banking plays a stronger role more on the borrowing side than on the depositors' side. The reason for this preference is the hesitancy in depositors' minds about deposit products, as they are unable to differentiate Islamic banking products from conventional banks' interest based savings deposit products. Consequently, Islamic banking needs to use different awareness campaigns to clarify the differences in the minds of perspective depositors. Among the control variables, GDP and financial development have a significantly positive impact on financial inclusion across all scenarios. This implies that a growing economy and financial sector developments across countries ultimately enhance financial inclusion. However, from our findings, we encourage policy makers to take steps to clarify the ambiguities in the mind of the general public regarding Islamic banking practices, especially regarding deposits products. This study investigates the impact of Islamic banking on financial inclusion in Muslim majority countries. Future studies may assess the impact of Islamic banking on financial inclusion in non-Muslim countries where Islamic finance is gaining greater acceptability.

\section{REFERENCES}

Ahmed, H. (2002). Financing microenterprises: An analytical study of Islamic microfinance institutions. Islamic Economic Studies, 9(2), 27-64.

Aysan, A. F., Disli, M., Ng, A., \& Ozturk, H. (2016). Is small the new big? Islamic banking for SMEs in Turkey. Economic Modelling, 54, 187-194.

doi: https://doi.org/10.1016/j.econmod.2015.12.031

Bauer, M., Chytilová, J., \& Morduch, J. (2012). Behavioral foundations of microcredit: Experimental and survey evidence from rural India. American Economic Review, 102(2), 1118-39. doi: https://doi.org/10.1257/aer.102.2.1118

Chiu, S., Newberger, R., \& Paulson, A. (2005). Islamic finance in the United States. Society, 42(6), 64-68. doi: https://doi.org/10.1007/BF02687517

Demirgüç-Kunt, A., Klapper, L., \& Randall, D. (2014). Islamic finance and financial inclusion: Measuring use of and demand for formal financial services among Muslim 
adults. Review of Middle East Economics and Finance, 10(2), 177-218.

doi: https://doi.org/10.1515/rmeef-2013-0062

Demirgüç-Kunt, A., Klapper, L., \& Singer, D. (2017). Financial inclusion and inclusive growth: A review of recent empirical evidence (Policy research working paper 8040). Washington, DC, WA: Development Research Group, World Bank.

Demirgüç-Kunt, A., Klapper, L., Singer, D., \& Van Oudheusden, P. (2015). The Global Findex Database 2014: measuring financial inclusion around the world (Working paper no. 7255). Washington, DC, WA: The World Bank.

El-Zoghbi, M., \& Tarazi, M. (2013). Trends in Sharia-compliant financial inclusion (Focus note 84). Washington, DC, WA: Consultative Group to Assist the Poor.

Fungáčová, Z., \& Weill, L. (2015). Understanding financial inclusion in China. China Economic Review, 34, 196-206. doi: https://doi.org/10.1016/j.chieco.2014.12.004

Ghosh, S., \& Vinod, D. (2017). What constrains financial inclusion for women? Evidence from Indian micro data. World Development, 92, 60-81.

doi: https://doi.org/10.1016/j.worlddev.2016.11.011

Hannig, A., \& S. Jansen (2010). Financial inclusion and financial stability: Current policy issues (ADBI working paper 259). Tokyo, Japan: Asian Development Bank Institute.

Hausman, J. A. (1978). Specification tests in econometrics. Econometrica, 46(6), 1251-1271. doi: https://doi.org/10.2307/1913827

ICD-Rifinitiv. (2019). Islamic finance development report, shifting dynamics. Retrieved from https://bit.ly/329mhRI

Imam, P., \& Kpodar, K. (2010). Islamic banking: How has it diffused? (IMF working paper WP/10/195) Washington DC, WA: International Monetary Fund.

Imam, P., \& Kpodar, K. (2016). Islamic banking: Good for growth? Economic Modelling, 59, 387-401. doi: https://doi.org/10.1016/j.econmod.2016.08.004

International Finance Corporation. (2014). Islamic banking opportunities across small and medium-sized enterprises in Egypt. Washington, DC, WA: International Finance Corporation, The World Bank Group. Retrieved from https://bit.ly/2SGrb5w

Iqbal, Z., \& Shafiq, B. (2015). Islamic finance and the role of Qard-al-hassan (benevolent loans) in enhancing inclusion: A case study of Akhuwat. ACRN Oxford Journal of Finance and Risk Perspectives Special Issue of Social and Sustainable Finance, 4(4), $23-40$

Islamic Financial Services Board. (2013). Islamic financial services industry stability report. Malaysia: Islamic Financial Services Board.

Jouti, T. A. (2018). Islamic finance: Financial inclusion or migration? ISRA International Journal of Islamic Finance, 10(2), 277-288. doi: https://doi.org/10.1108/ijif-07-2018-0074

Léon, F., \& Weill, L. (2018). Islamic banking development and access to credit. PacificBasin Finance Journal, 52, 54-69.

doi: https://doi.org/10.1016/j.pacfin.2017.04.010

Love, I., \& Pería, M. S. (2015). How bank competition affects firms' access to finance. The World Bank Economic Review, 29(3), 413-448. doi: https://doi.org/10.2139/ssrn.2144888 
Mohieldin, M., Iqbal, Z., Rostom, A., \& Fu, X. (2012). The role of Islamic finance in enhancing financial inclusion in Organization of Islamic Cooperation (OIC) countries. Islamic Economic Studies, 20(2), 55-119.

Naceur, S. B., Barajas, A., \& Massara, A. (2015). Can Islamic banking increase financial inclusion? (IMF working paper no. 31). Washington, DC, WA: International Monetary Fund.

Sahay, R., Čihák, M., N’Diaye, P., Barajas, A., Mitra, S., Kyobe, A., Mooi, Y. N., \& Yousefi, S. R. (2015). Financial inclusion-can it meet multiple macroeconomic goals? (IMF Staff discussion note, SDN/15/17). Washington DC, WA: International Monetary Fund.

Shaikh, S. A., Ismail, M. A., Shafiai, M. H. M., Ismail, A. G., \& Shahimi, S. (2017). Role of Islamic banking in financial inclusion: Prospects and performance. In Islamic banking (pp. 33-49). Cham, Switzerland: Palgrave Macmillan.

Shinkafi, A. A., Yahaya, S., \& Sani, T. A. (2019). Realising financial inclusion in Islamic finance. Journal of Islamic Marketing, 11(1), 143-160.

doi: https://doi.org/10.1108/JIMA-02-2017-0020

Sinclair, S. P. (2001). Financial exclusion: An introductory survey centre for research into socially inclusive services. Retrieved from https://bit.ly/3bPE1pw

Weill, L. (2011). Do Islamic banks have greater market power? Comparative Economic Studies, 53(2), 291-306. doi: https://doi.org/10.1057/ces.2011.1

Weill, L., \& Godlewski, C. (2014). Why do large firms opt for Islamic loans? Comparative Economic Studies, 56(1), 132-153. doi: https://doi.org/10.1057/ces.2013.26

World Bank (2014). Global Financial Development Report (GFDR). Washington, DC: World Bank.

Zinsa, A., \& Weill, L. (2016). The determinants of financial inclusion in Africa. Review of Development Finance, 6, 46-57. doi: https://doi.org/10.1016/j.rdf.2016.05.001 


\section{APPENDICES}

\section{Appendix I}

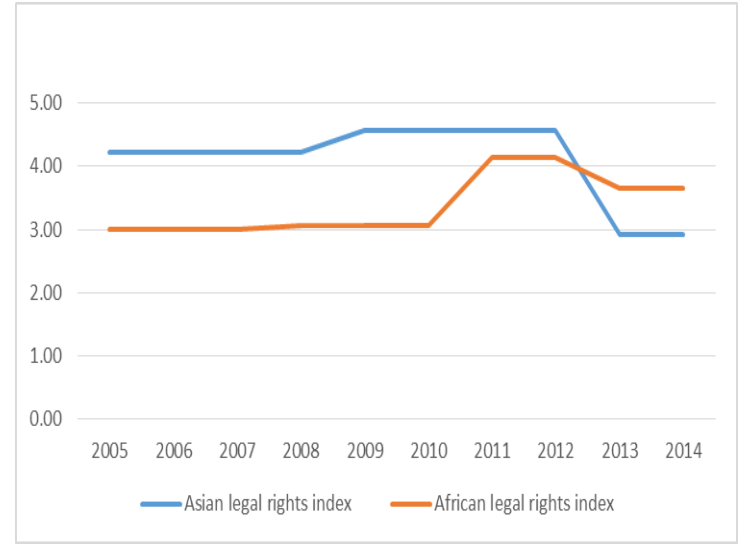

FIGURE 1. Legal rights

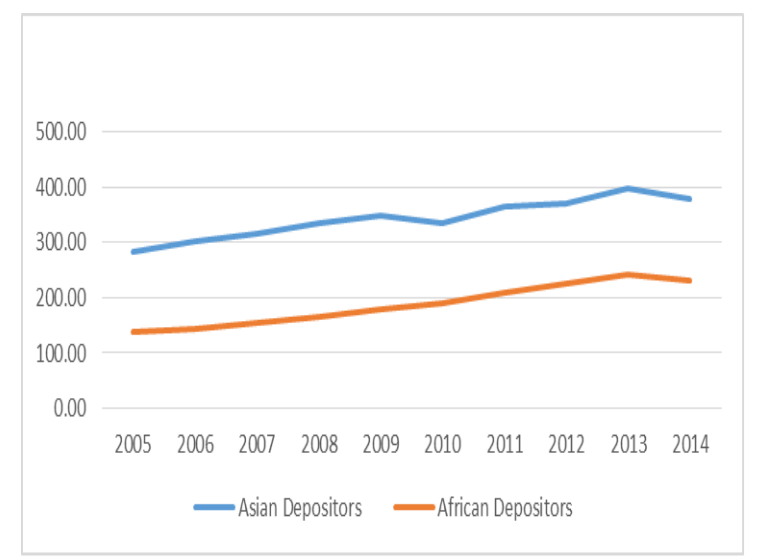

FIGURE 2. Number of depositors/1000 adults

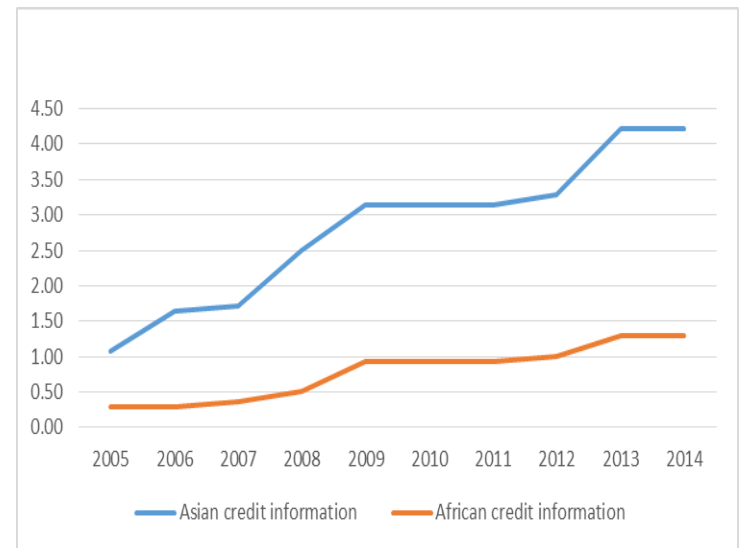

FIGURE 3. Financial information

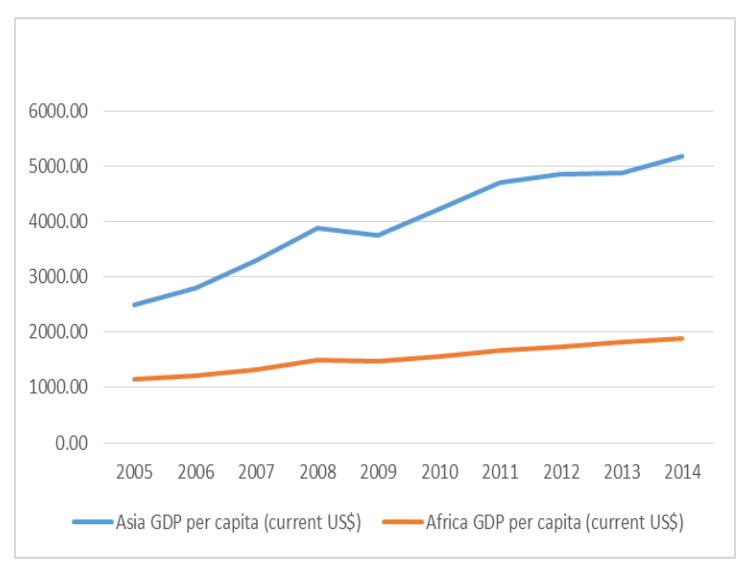

FIGURE 4. GDP per Capita

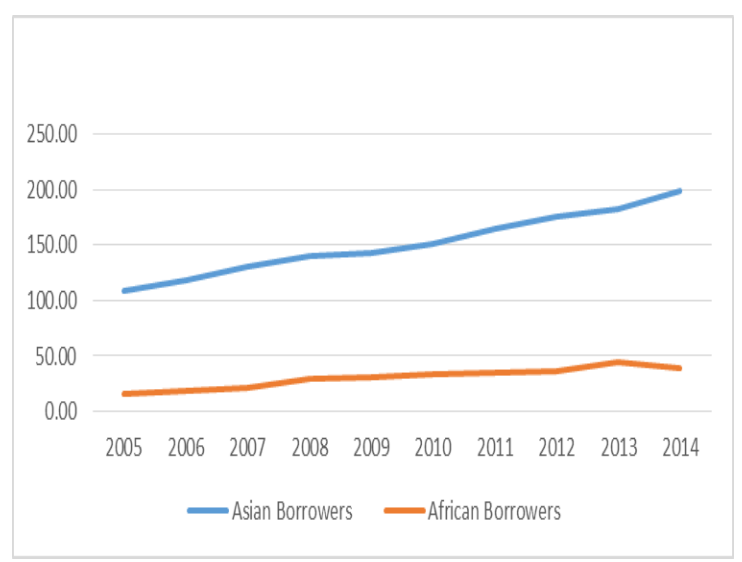

FIGURE 5. Number of borrowers/1000 adults

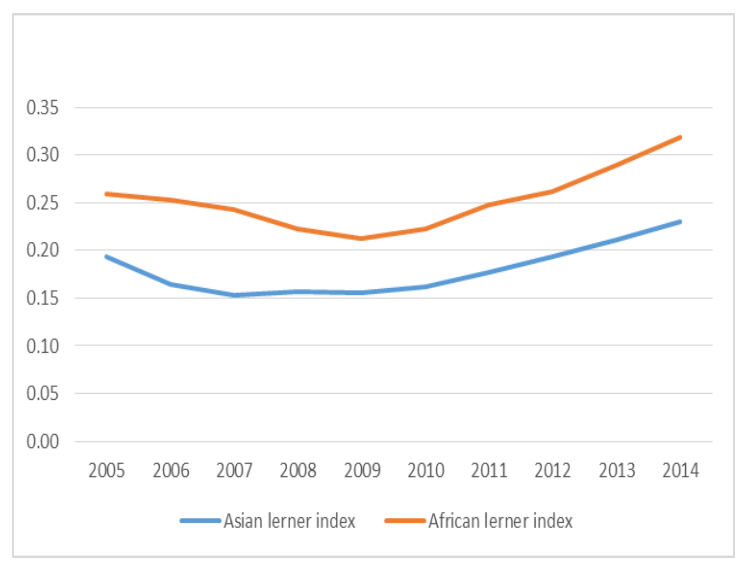

FIGURE 6. Banking competition 


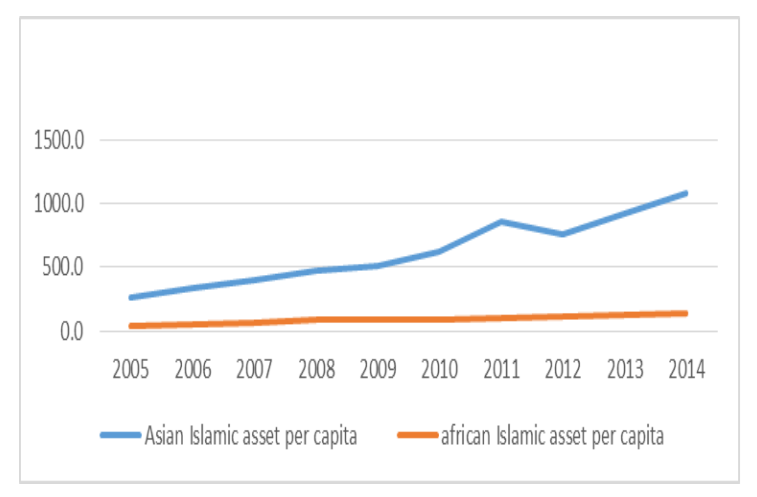

FIGURE 7. Islamic banking assets per capita 


\section{Appendix II: List of Sample Countries}

Asian Countries: Afghanistan, Azerbaijan, Bangladesh, Indonesia, Iran, Iraq, Jordan, Lebanon, Malaysia, Maldives, Pakistan, Turkey, Gaza, Yemen

African Countries: Algeria, Burkina Faso, Cameroon, Ivory Coast, Djibouti, Egypt, Gambia, Mauritania, Nigeria, Senegal, Sudan, Syria, Tunisia, Uganda 